\title{
Manajemen Produksi Siaran Berita Liputan 6 SCTV Selama Pandemi
}

\section{Covid-19}

\section{Failasuf Ramadhan}

Program Studi Ilmu Komunikasi, Universitas Muhammadiyah Yogyakarta, Indonesia filsuframadhan@gmail.com

Audrey Vania Zachrani Kinasih

Program Studi Ilmu Komunikasi, Universitas Muhammadiyah Yogyakarta, Indonesia a.v.zachrani.kinasih@gmail.com

Ditha Aditya Pernikasari

Program Studi Ilmu Komunikasi, Universitas Muhammadiyah Yogyakarta, Indonesia dita9729@gmail.com

Diserahkan: 21 Mei 2021; Direvisi: 10 Juni 2021; Diterima: 10 Juni 2021

\begin{abstract}
Research background is broadcasting media adaptation during pandemic. This study aims to determine the production management of news broadcasts on Liputan 6 during the corona virus pandemic in line with the distance limitation policy that occurs in DKI Jakarta. In addition, are there any changes that have occurred in the production process of news broadcasts in Liputan 6 SCTV. This research is also to find out how Liputan 6 SCTV as one of the media industry's programs in adapting during the Covid-19 pandemic. This research uses a case study method. Data collection methods are carried out by in-depth interviews, documents, archives and several cases. Based on the results of the analysis, initially the interviews in reportage were conducted directly with the informants. However, during the Covid-19 pandemic interviews were conducted using intermediaries media conferencing such as zoom, skype, and others. If the coverage activity is intended for the red zone area, then the coverage is carried out at a distance of 100 meters using intermediaries from sources who live in the area to obtain accurate information.
\end{abstract}

Keywords: Covid-19, News Release Production Management, Liputan 6 SCTV.

\begin{abstract}
Abstrak
Latar belakang penelitian ini adalah adaptasi media penyiaran di masa pandemi. Penelitian ini bertujuan untuk mengetahui manajemen produksi siaran berita di Liputan 6 SCTV selama pandemi virus Corona seiring adanya kebijakan pembatasan jarak yang terjadi di DKI Jakarta. Selain itu juga, adakah perubahan yang terjadi dalam proses produksi siaran berita di Liputan 6 SCTV. Penelitian ini juga untuk mengetahui bagaimana cara Liputan 6 SCTV sebagai salah satu program dari industri media dalam beradaptasi selama masa pandemi Covid-19. Penelitian ini menggunakan metode studi kasus. Metode pengumpulan data dilakukan dengan wawancara mendalam, dokumen, arsip dan beberapa kasus. Berdasarkan hasil analisis, awalnya dalam peliputan berita, reporter melakukan wawancara dilakukan secara langsung dengan narasumber. Namun, selama pandemi Covid-19 wawancara dilakukan dengan menggunakan perantara media conference seperti zoom, skype, dan lainnya. Apabila kegiatan liputan diperuntukkan di daerah zona merah maka liputan dilakukan dengan jarak 100 meter memanfaatkan perantara dari narasumber yang tinggal di daerah tersebut untuk mendapatkan informasi yang akurat.

Kata Kunci: Covid-19, Manajemen Produksi Siaran Berita, Liputan 6 SCTV.
\end{abstract}




\section{PENDAHULUAN}

Akhir tahun 2019, dunia dikejutkan dengan berita adanya penemuan virus baru yang berasal dari Wuhan, China. Virus tersebut dikenal dengan nama Virus Corona atau Covid-19. Penyebaran virus corona di Indonesia pertama kali dilaporkan pada 2 Maret 2020. Di Indonesia sendiri, pasien pertama yang diumumkan oleh Presiden Joko Widodo yang terjangkit berjumlah 2 orang berasal dari Daerah Depok, Jakarta. Dalam kurun waktu kurang dari seminggu setelah terdapat pasien positif, pemberitaan di media dipenuhi dengan berita tentang perkembangan virus tersebut, identitas pasien, upaya pencegahan dan kemungkinan-kemungkinan yang akan terjadi baik secara kesehatan, ekonomi dan sosial.

Fenomena maraknya penyebaran virus corona di Indonesia menyebabkan pemerintah menerapkan kebijakan Pembatasan Sosial Berskala Besar (PSBB) yang bertujuan untuk mengurangi penyebaran virus secara akurat. Adanya kebijakan ini membuat masyarakat dilarang melakukan aktivitas diluar rumah, kecuali untuk kegiatan yang diperbolehkan. Kapasitas penumpang dan jam operasional transportasi umum dibatasi untuk menjaga penerapan physical distancing.

Pandemi virus corona ini menciptakan rasa takut dan khawatir di Indonesia. Semakin hari kian meningkat pasien positif virus corona. Hal ini membuat pemerintah harus lebih serius dalam menangani penyebaran virus corona diikuti peran masyarakat untuk menaati protokol kesehatan yang telah ditentukan seperti menjaga jarak, mengenakan masker, menjaga kebersihan dan jangan menyentuh benda-benda di tempat umum.

Kebijakan penerapan PSBB yang diberlakukan dibeberapa daerah khususnya di daerah ibu kota mempengaruhi aktivitas beberapa sektor. Berdasarkan peraturan Gubernur Nomor 33 Tahun 2020 tentang pelaksanaan Pembatasan Sosial Berskala Besar (PSBB) di DKI Jakarta, terdapat sektor-sektor yang diizinkan untuk beroperasi dikala pandemi virus corona. Seperti kesehatan, keuangan, komunikasi dan teknologi, bahan pangan dan lain sebagainya. Komunikasi termasuk ke dalam sektor yang di perbolehkan beroperasi diantaranya industri media massa (Suprayitno, 2020).

Berdasarkan penelitian terdahulu dari Khatimah menyatakan bahwa media massa merupakan sarana komunikasi massa yang berperan sebagai komunikator serta agent of change yakni pelopor perubahan dalam lingkungan publik yang dapat mempengaruhi khalayak melalui pesan berupa informasi, hiburan, pendidikan maupun pesan-pesan lainnya dan dapat dijangkau masyarakat secara luas (Khatimah, 2018).

Ketika pandemi ini banyak orang yang mengalami kecemasan karena menerima banyaknya berita mengenai Covid-19 dari berbagai sumber. Entah dari sumber terpercaya maupun sumber yang tidak dapat dipercaya kebenarannya. Dari sinilah media massa memiliki peran penting untuk setidaknya mengatasi kecemasan yang dialami oleh penonton karena adanya peran dari media massa yaitu, media massa sering dipandang sebagai guide, petunjuk jalan atau interpreter, yang menerjemahkan dan menunjukkan arah atas berbagai ketidakpastian, atau alternatif yang beragam. Kemudian, memandang media massa sebagai filter, atau gatekeeper yang menyeleksi berbagai hal untuk diberi perhatian atau tidak. Televisi senantiasa memilih isu, informasi atau bentuk content yang lain berdasarkan standar para pengelolanya. Selain itu media massa sebagai interlocutor, yang tidak hanya sekedar tempat berlalu lalangnya informasi, tetapi juga partner komunikasi yang memungkinkan terjadinya komunikasi interaktif (Khatimah, 2018).

Selaras dengan hasil penelitian terdahulu dari (Syaipudin, 2020) menjelaskan bahwa pemanfaatan media massa yang baik, semakin membuka peluang dalam hal penyelesaian permasalahan yang timbul. Bahkan, permasalahan-permasalahan tersebut bukan sekedar masalah sederhana, melainkan permasalahan yang timvul dan melibatkan orang banyak seperti pandemi Covid-19. Untuk itu, diperlukan jalinan komunikasi dan pemanfaatan media massa guna memberikan edukasi secara berkesinambungan terhadap masyarakat luas.

Walaupun media massa tetap beroperasi selama pandemi tentunya manajemen siaran yang dilakukan sangatlah berbeda dengan bagaimana dilakukannya sebelum pandemi melanda. Apalagi 
sektor media seperti ini Liputan 6 SCTV bukanlah suatu bidang pekerjaan yang bisa dilakukan sendiri namun harus melibatkan banyak orang atau crew untuk bertugas. Ditambah lagi pekerjaan sektor media massa juga membutuhkan keterlibatan langsung dengan orang banyak seperti dalam kegiatan peliputan lapangan dan harus bertemu dengan narasumber secara langsung untuk mendapatkan kesaksian ataupun sumber yang kredibel.

Berdasarkan latar belakang masalah tersebut, rumusan masalah penelitian ini antara lain : bagaimana manajemen produksi siaran berita khususnya di Liputan 6 SCTV selama pandemi virus Corona? Perubahan apa saja yang signifikan terjadi dalam proses produksi siaran? Bagaimana cara beradaptasi di tengah pandemi saat ini?

Penelitian ini bertujuan untuk mengetahui manajemen produksi siaran berita di Liputan 6 SCTV selama pandemi virus corona seiring adanya kebijakan pembatasan jarak yang terjadi di DKI Jakarta. Selain itu juga, adakah perubahan yang terjadi dalam proses produksi siaran berita di Liputan 6 SCTV. Penelitian ini juga untuk mengetahui bagaimana cara Liputan 6 SCTV sebagai salah satu program dari industri media dalam beradaptasi selama masa pandemi Covid-19.

Penelitian terdahulu membahas tentang perubahan pola liputan reporter di stasiun televisi CNBC selama masa pandemi yang dilakukan Supriyanto, selain itu penelitian ini membahas terkait proses perubahan produksi dan juga adaptasi media elektronik terhadap perubahan teknologi (Suprayitno, 2020). Berbeda dengan penelitian di atas, penelitian ini berfokus terkait perubahan keseluruhan mulai dari pra produksi hingga pasca produksi atau hal-hal yang terjadi pada proses manajemen produksi siaran berita sekaligus cara Liputan 6 SCTV sebagai program dari industri media dalam melakukan adaptasi selama pandemi Covid-19.

\section{KAJIAN PUSTAKA}

\section{ADAPTASI KOMUNIKASI DI MASA PANDEMI}

Media sesungguhnya merupakan bagian dari ruang publik yang memungkinkan terjadinya pertukaran informasi dan pandangan terkait kepentingan orang banyak sehingga dapat menyuarakan opini publik. Ruang publik akan terjadi ketika masyarakat menggunakan haknya untuk mengerluarkan pendapatnya yang dianggap penting.

Media massa pada saat ini menyajikan informasi dengan melalui media cetak maupun elektronik. Media cetak terdiri dari surat kabar, tabloid dan majalah. Sedangkan media elektronik terdiri dari radio siaran dan televisi siaran. Akan tetapi masyarakat Indonesia lebih mudah menerima informasi yang disampaikan media elektronik yaitu televisi. Televisi mempunyai banyak keunggulan dibandingkan dengan media massa lainnya.

Pertama, pesan yang disampaikan televisi disajikan secara audio visual, yang berbeda dengan radio yang hanya menyampaikan dengan audio (melalui pendengaran) dan surat kabar yang bersifat visual saja (melalui penglihatan). Televisi unggul dalam membangun daya tarik, persepsi perhatian dan imajinasi dalam mengkonstruksi realitas. Kedua, dilihat dari sisi aktualitas peristiwa, televisi bisa lebih cepat memberikan informasi kepada pemirsa daripada surat kabar, radio, dan majalah. Ketiga, dari segi khalayak televisi menjangkau ratusan ribu pemirsa. Keempat, efek kultural televisi lebih besar dari efek yang dihasilkan iklan dari jenis-jenis lainnya media lainnya (Raharjo, 2015).

Gambaran tentang realitas yang dibentuk oleh isi media massa inilah yang kemudian akan mendasari respon dan sikap khalayak terhadap berbagai objek sosial. Kesalahan dalam proses pemberitaan akan membuat audience menerima pesan yang tidak lengkap, sehingga menimbulkan gambaran yang salah pula terhadap objek sosial, oleh karenanya media massa dituntut menyampaikan informasi secara akurat dan berkualitas.

Dengan adanya hal tersebut media televisi nampaknya dituntut untuk membuat program-program acara yang unik dan berbeda dengan acara-acara lainnya. Selain melalui program-program nya yang unik, pembentukan image ini bisa juga dilakukan dengan bagaimana hubungan media dengan khalayak. 
Dalam situasi krisis, manajemen komunikasi publik penting untuk mengurangi kesenjangan (gap) informasi. Untuk itu, strategi komunikasi publik perlu memperhatikan suara publik (Kriyantono\& Sa'diyah, 2018). Pola ini sebagai umpan balik (input) terhadap aktivitas komunikasi interaktif lembaga, yang mengikutsertakan keterlibatan publik (pubic involvement) dalam penanganan krisis. Pola komunikasi dinamis masyarakat di tengah gempuran teknologi digital, membuat publik mampu mengakses informasi dengan aktif dan cepat. Faktualitas dan aktualitas informasi menjadi kunci penanganan krisis. Media sosial berperan untuk menjembatani kesenjangan akses informasi ini. Namun, menurut Haryanti \& Rusfian (2018), perbedaan sumber daya sosial, ekonomi, budaya, dan pengetahuan masyarakat menimbulkan perbedaan akses publik atas media sosial

Oleh karena itu, komunikasi publik yang efektif di masa krisis tidak hanya mengandalkan media digital, namun harus mengoptimalkan kombinasi media digital dan konvensional. Misalnya penggunaan jalur komunikasi tradisional atau lokal, media massa, media sosial, aplikasi chat, jaringan kreatif (Ramadani, 2019). Juga jalur pemuka pendapat (opinion leader, influencer), lembaga pendidikan (kampus, sekolah), lembaga keagamaan, sosial, birokrasi lokal (RT, RW), dan sebagainya. Penggunaan saluran komunikasi langsung di lapangan diperlukan, agar dapat menyerapkan tanggapan masyarakat dan mempercepat penyampaian informasi dari pemerintah.

Penanganan informasi publik pandemi Covid-19 adalah bagian dari komunikasi bencana (krisis) dan komunikasi kesehatan. William J. Paisley dalam tulisannya Public Communication Campaigns: "The american Experience" dalam Rice \& Atkin (2001), menjelaskan bahwa penyampaian informasi kesehatan publik dianggap aplikasi pelayanan publik, jika didukung publik dan pembuat kebijakan (pemerintah). Robert A. Logan menulis mengenai Health Campaign Research dalam Bucchi \& Trench (2008), menjelaskan komunikasi publik mengenai kesehatan bersifat informatif dan persuasif. Tujuannya untuk mengubah pengetahuan, kesadaran, dan sikap publik mengenai cara mengatasi suatu penyakit atau kesehatan.

\section{MANAJEMEN PRODUKSI BERITA TELEVISI}

Menurut Wayne Mondy (1983) dan rekan mendefinisikan manajemen yang lebih berfokus pada faktor manusia dan materi sebagai proses perencanaan, pengorganisasian, memengaruhi dan pengawasan untuk mencapai tujuan organisasi melalui koordinasi penggunaan sumber daya manusia dan materi. Manajemen sendiri sangat penting bagi sebuah perusahaan maupun organisasi karena tanpa adanya manajemen semua akan sia-sia dan sulit untuk mencapai tujuan yang diinginkan. Konsep manajemen tetap mengacu pada perencanaan, pengorganisasian, pengarahan, dan pengendalian (Batlajery, 2016).

1. Manajemen sebagai proses kegiatan

Sebagai suatu proses kegiatan, manajemen diartikan sebagai suatu rangkaian kegiatan yang dimulai dari kegiatan merencanakan, melaksanakan serta mengkoordinasikan apa yang direncanakan sampai dengan kegiatan mengawasi atau mengendalikannya agar sesuai dengan apa yang direncanakan.

2. Manajemen sebagai suatu ilmu dan seni

Manajemen sebagai ilmu dan seni diartikan sebagai usaha pencapaian tujuan dengan pendekatan dan menjelaskan fenomena-fenomena dan gejala-gejala manajemen serta mentransformasikan dan mengindentifikasikan proses manajemen berdasarkan kaida- kaida ilmiah.

3. Manajemen sebagai kumpulan orang untuk mencapai tujuan

Setiap kegiatan yang dilakukan oleh dua orang atau lebih secara kooperatif dalam organisasi disebut sebagai aktivitas manajemen. Kolektivitas orang-orang tersebut bergabung dalam suatu organisasi dan dipimpin oleh seorang pemimpin (manajer) yang bertanggung jawab penuh atas usaha pencapaian tujuan secara efisien dan efektif. 
Berikut tahapan-tahapan produksi program televisi diantaranya:

1. Praproduksi

Tahap pra produksi adalah tahap pencarian data awal oleh penulis yang menjadi pedoman melakukan tahap produksi, data yang didapat kemudian dijadikan bahan untuk menentukan alur dari video campaign yang akan dibuat. Sebelum masuk ketahap produksi, yang perlu dipersiapkan dahulu adalah storyline, storyboard dan script berdasarkan data yang sudah diperoleh.

2. Produksi

Tahap produksi adalah seluruh kegiatan pengambilan gambar (shooting) baik di studio maupun diluar studio. Proses ini disebut juga dengan taping. Perlu dilakukan pemeriksaan ulang setelah kegiatan pengambilan gambar selesai dilakukan. Jika terjadi kesalahan maka pengambilan gambar dapat diulang kembali.

3. Pascaproduksi

Tahap pasca-produksi adalah semua kegiatan setelah pengambilan gambar sampai materi itu dinyatakan selesai dan siap disiarkan atau diputar kembali. (Morissan, 2013). Dalam tahapan pasca-produksi program yang sudah di rekam harus melalui beberapa proses, diantaranya editing, narasi, mixing, dan mastering

\section{METODE PENELITIAN}

Penelitian ini dilaksanakan dengan menggunakan metode studi kasus. Penelitian dengan metode studi kasus penelitian memiliki tujuan untuk menguji pertanyaan dan masalah penelitian, yang tidak dapat dipisahkan antara fenomena serta konteks dimana fenomena tersebut terjadi. Dalam hal ini, studi kasus digunakan untuk meneliti fenomena tentang Manajemen Produksi Siaran Berita Liputan 6 SCTV Selama Pandemi Covid-19.

Penggunaan metode penelitian studi kasus dilakukan dengan mempertimbangkan beberapa hal. Pertama, fokus penelitian adalah untuk menjawab pertanyaan "bagaimana" dan "mengapa". Kedua, dalam penelitian studi kasus, peneliti tidak boleh memanipulasi perilaku obyek yang diteliti yang terlibat didalam penelitian. Ketiga, peneliti ingin menutupi kondisi kontekstual dilatarbelakangi karena peneliti memiliki keyakinan bahwa hal itu relevan dengan yang diteliti. Terakhir, adanya batas tidak jelas antara fenomena dan konteks yang diteliti (Yin, 2008). Dalam penelitian ini, studi kasus dilaksanakan dengan meneliti proses manajemen produksi siaran berita liputan 6 sctv selama pandemi Covid-19.

Metode pengumpulan data dalam penelitian studi kasus ini adalah dilakukan dengan berbagai cara. Pertama adalah dengan wawancara mendalam. Kekuatan utama wawancara sebagai metode adalah kemampuannya untuk menjangkau berbagai perspektif tentang topik tertentu. Berbagai wawancara dapat digunakan untuk menambah informasi dan memperluas sudut pandang. Semua wawancara dapat digunakan sebagai perangkat heuristik, karena informasi baru mengarah pada perspektif dan pertanyaan baru untuk subjek selanjutnya (Given, 2008) Dalam penelitian ini, wawancara akan dilakukan kepada Reza Ramadhansyah, yang menjabat sebagai News Anchor di Liputan 6 SCTV.

Kedua adalah dengan studi dokumen dan arsip. Dokumen, bisa berupa surat, memorandum, agenda, dokumen administrasi, artikel surat kabar, atau dokumen apapun yang berkaitan dengan penyelidikan. Uji validitas bukti dengan dokumen berfungsi untuk menguatkan bukti dari sumber lain. Dokumen juga dapat dipakai guna menarik kesimpulan pada suatu peristiwa, mengarah pada petunjuk palsu jika peneliti tidak berpengalaman. Dokumen dapat berbentuk arsip, seperti catatan layanan, catatan organisasi, daftar nama, hasil survey (Yin, 2008). Pada penelitian ini, arsip yang diteliti adalah dokumen yang bersumber dan berkaitan dengan manajemen produksi siaran berita liputan 6 sctv selama pandemi Covid-19.

Setelah data terkumpul, dilakukan proses reduksi data dengan memilah data yang bisa digunakan dan diabaikan. Data yang terpilih selanjutnya dianalisis dengan menggunakan analisis data studi kasus 
yang dilakukan dengan melakukan kategori data. Setelah ada kategori data, dilanjutkan dengan mengatur data dengan empat cara, yaitu pencocokan pola, membangun penjelasan, menemukan logika model, dan melakukan analisis timeseries (Yin, 2008).

Teknik tambahan dilakukan ketika menggunakan beberapa kasus, disebut sebagai sintesis untuk mencari pengulangan dalam kasus. Produk akhirnya adalah narasi yang menceritakan tentang kasus, yang memungkinkan pembaca sepenuhnya menjadi paham pada pada kasus yang terjadi (Prihatsanti et al., 2018).

\section{HASIL DAN PEMBAHASAN}

\section{PRODUKSI SIARAN BERITA LIPUTAN 6 SCTV}

Proses produksi siaran berita Liputan 6 sangat mengedepankan kecepatan dalam kegiatan produksi maupun penyajian hasil karya kepada audience. Informasi atau pesan yang disampaikan harus faktual dan mengandung nilai penting serta menarik untuk dikonsumsi oleh khalayak. Dalam proses produksi yang bersifat terikat dengan waktu menyebabkan proses perencanaan, produksi dan editing harus dilakukan secara cepat guna mengejar nilai aktualitas berita. Setiap kegiatan produksi siaran berita Liputan 6 SCTV memerlukan beberapa tahapan dalam pelaksanaan produksi yang jelas dan efisien. Tahapan produksi ini terdiri dari 3 bagian yang sesuai dengan Standard Operational Procedure (SOP) sebagai berikut :

1. Pra Produksi (Perencanaan)

Pra Produksi sangatlah penting, karena tahap ini merupakan perencanaan dari serangkaian kegiatan produksi yang akan dilaksanakan. Apabila tahap ini dilakukan dengan detail dan baik, hasilnya pun akan sesuai dengan apa yang telah direncanakan.

2. Produksi (Peliputan)

Tahap ini merupakan seluruh kegiatan terkait peliputan berita yang berlangsung di studio maupun lapangan.

3. Pasca Produksi (Penyuntingan)

Merupakan tahapan yang memuat kegiatan usai peliputan, penulisan naskah, editing/penyuntingan, pengisian suara sampai materi itu dinyatakan selesai dan siap untuk disiarkan kepada khalayak.

Pengertian manajemen produksi pada operasional stasiun penyiaran adalah penyiapan acara-acara yang akan disiarkan. Penyiapan acara memegang peranan penting. Penyiapan acara bisa dilakukan menggunakan pembelian kepada pihak lain (Production House) baik pada juga luar negeri atau menghasilkan acara-acara yang akan disiarkan. Oleh lantaran itu, setiap stasiun televisi mempunyai bagian yang dianggap bagian produksi. Kegiatan produksi pada stasiun penyiaran perlu dikelola menggunakan baik. Pengelolaan yang baik menyebabkan produksi wajib melalui langkah-langkah yang terdapat pada manajemen. Kata manajemen merupakan terjemahan menurut istilah pada bahasa inggris "management". Menurut asal pungkasnya management bisa diartikan menjadi proses mengarahkan dan memfasilitasi orang-orang secara organisir pada grup buat mencapai tujuan yang diharapkan.

"Proses manajemen produksi siaran berita Liputan 6 SCTV selama pandemi dimulai dengan mengikuti peraturan Pemerintah Pusat maupun Daerah seperti pembatasan karyawan. Dengan adanya peraturan tersebut maka dibuatlah jadwal shift dan membedakan ruangan antara pekerja lapangan dengan pekerja kantornya serta mereka dilarang untuk saling bertemu”. (Reza Ramadhansyah, wawancara, 18 April 2021)

Hal ini dilakukan untuk menekan penularan virus Covid-19. Selain itu yang awalnya wawancara dilakukan secara langsung secara tatap muka dengan narasumber namun sekarang dilakukan dengan menggunakan perantara media conference seperti zoom, skype, dan lainnya. Namun liputan tetap dilakukan secara langsung apabila dalam liputan bencana dan crew wajib menerapkan protokol kesehatan. Apabila dibutuhkan liputan pemberitaan Covid-19 yang diperuntukkan di daerah zona 
merah maka liputan tidak dilakukan langsung dari zona merah tersebut namun melalui perantara dari narasumber yang tinggal di daerah tersebut ataupun perantara media.

\section{PERUBAHAN MANAJEMEN PRODUKSI SIARAN BERITA LIPUTAN 6 SCTV MASA PANDEMI COVID-19}

Proses berita televisi yang merupakan bagian dari manajemen. Idealnya tahapan- tahapan produksi program televisi harus dijalani secara berurutan. Artinya, tahapan pertama harus diselesaikan sebelum bisa melanjutkan ke tahapan berikutnya. Namun, berbeda dengan proses produksi program nonberita atau nonfiksi lainnya, produksi program berita televisi dilakukan dengan cepat, bahkan pada kondisi situasi tertentu tahapan satu selesai sebelum bisa memulai ke tahap selanjutnya.

Kadangkala, ketika mengejar tayang suatu peristiwa besar agar tidak didahului competitor, materi berita (gambar saja) ditayangkan/digelontorkan (di-roll) tanpa tahapan akhir yang sempurna. Produksi berita telvisi memanfaatkan atau memburu materi audiovisual apa adanya tanpa manipulasi (karya jurnalistik), sehingga gambar yang ditayangkan " as it happen" atau saat sebuah peristiwa yang sedang berlangsung. Pandemi Covid-19 menyebabkan perubahan dalam proses produksi.

Untuk mendapatkan informasi yang akurat dan maksimal tim liputan berkolaborasi dengan masyarakat melalui media sosial dan tentunya mengecek kevalidan dan kebenaran terkait infonya. Liputan 6 SCTV menerapkan protokol kesehatan secara ketat sejak tanggal 18 Maret 2020 atau dua minggu setelah kasus pertama Covid-19 ditemukan di Indonesia kepada para stafnya.

Liputan 6 SCTV masih menerapkan protokol kesehatan dengan ketat seperti melakukan swab kepada para staf dua minggu sekali, suntik vitamin hingga pelarangan menggunakan transportasi umum. Untuk bisa masuk ke dalam gedung para staf harus menggunakan ID card mereka karena di dalamnya sudah terdapat informasi apakah staf tersebut sudah melakukan swab antigen atau belum. Untuk tamu yang berkunjung diwajibkan untuk membawa surat keterangan sehat atau terbukti negatif dari virus corona melalui tes swab antigen.

\section{KESIMPULAN}

Manajemen produksi siaran berita liputan 6 SCTV selama masa pandemi Covid-19 menerapkan protokol kesehatan yang sangat ketat bagi para pekerja dan staffnya, hal ini untuk mengantisispasi adanya penularan virus Covid-19. Aturan ini mulai diberlakukan pada tanggal 18 Maret 2020. Selain menerapkan protokol kesehatan yang sangat ketat, manajemen produksi siaran berita diubah sedemikian rupa untuk menyesuaikan terhadap perubahan keadaan yang diakibatkan oleh pandemi Covid-19. Seluruh koordinasi antar narasumber berita maupun crew yang ada di Liputan 6 SCTV memanfaatkan media conference seperti zoom, skype, dan lainnya. Kegiatan peliputan tetap dilakukan secara langsung sekalipun pada daerah yang tergolong zona merah. Namun, kegiatan ini dilakukan dengan jarak 100 meter dan berkolaborasi dengan masyarakat yang tinggal di daerah tersebut untuk mendapatkan informasi yang valid dan akurat. Hingga saat ini Liputan 6 SCTV masih melakukan pemeriksaan swab kepada para staff serta pemberian suntik vitamin. Adapun untuk tamu yang berkunjung diwajibkan membawa surat keterangan negatif melalui tes swab antigen.

\section{PERSANTUNAN}

Terima kasih kepada Dr. Fajar Junaedi yang telah membimbing proses riset jurnal mengenai Manajemen Produksi Siaran Berita Liputan 6 SCTV Selama Pandemi Covid-19 dalam mata kuliah Media Penyiaran di Program Studi Ilmu Komunikasi UMY, selama satu semester genap tahun akademik 2020/2021 yang menghasilkan luaran berupa artikel ini.

\section{REFERENSI}

Ahmad Qorib, MA. M. Yoeserizal Saragih, M.ikom. 2019. Pengantar Jurnalistik. Indonesia :

Guepedia

Basuki, K. (2019). MANAJEMEN PRODUKSI PROGRAM BERITA DI TELEVISI LOKAL (Studi 
Pada Manakarra TV Dikota Mamuju). ISSN 2502-3632 (Online) ISSN 2356-0304 (Paper)

Jurnal Online Internasional \& Nasional Vol. 7 No.1, Januari - Juni 2019 Universitas 17 Agustus 1945 Jakarta, 53(9), 1689-1699. www.journal.uta45jakarta.ac.id

Batlajery, S. (2016). Penerapan Fungsi-Fungsi Manajemen Pada Aparatur Pemerintahan Kampung

Tambat Kabupaten Merauke. Jurnal Ilmu Ekonomi \& Sosial, 7(2), 135-155.

https://doi.org/10.35724/jies.v7i2.507

Fachruddin, Andi. 2017. Dasar-Dasar Produksi Televisi : Produksi Berita, Feature, Laporan

Investigasi, Dokumentasi, dan Teknik Editing. Indonesia : Prenadamedia Group.

Fadhal, Soraya, dkk. 2020. Media, Komunikasi dan Informasi di Masa Pandemi Covid-19. Indonesia :

MBridge Press

Khatimah, H. (2018). Posisi Dan Peran Media Dalam Kehidupan Masyarakat. Tasamuh, 16(1), 119138. https://doi.org/10.20414/tasamuh.v16i1.548

Morissan, M.A. 2018. Manajemen Media Penyiaran : Strategi Mengelola Radio \& Televisi. Jakarta : Kencana.

Pujianti, L. (2010). Analisis Deskriptif Manajemen Produksi Siaran Berita Berbahasa Betawi Bandar Jakarta di Stasiun JAK TV.

Suprayitno, D. (2020). Perubahan Pola Liputan Reporter Tv Selama Pandemi Covid-19. J-Ika, 7(2), 137-147. https://doi.org/10.31294/kom.v7i2.8402

Studi, P., Terapan, K., Penyiaran, D. I. I. I., Ilmu, F., Dan, S., Politik, I., \& Maret, U. S. (2010). Proses Produksi Program Berita Liputan 6 Siang Di Pt. Surya Citra Televisi ( Sctv ). 1-68.

Syaipudin, L. (2020). Peran Komunikasi Massa Di Tengah Pandemi Covid-19. Kalijaga, 2(1), 14-34. Yusuf, I. A., Zuhri, S., Adiputra, W. M., Siregar, A. E., Sampul, D., \& Poerwaningtyas, I. (n.d.).

Perpustakaan Nasional RI : Katalog Dalam Terbitan (KDT) Puji Rianto, dkk. Kepemilikan / Puji Rianto dkk .; Penyunting, Intania Poerwaningtyas Yogyakarta : PR2Media-Yayasan Tifa, 2012 ISBN : 978-602-97839-2-6. 